RESEÑAS

Chantal Maillard (ed.). El árbol de la vida. La naturaleza en el arte y las tradiciones de la India, 2001, Barcelona, Kairós.

\title{
La naturaleza a través del mito, el arte y la filosofía
}

Debido a la necesidad de preservar la vida en la Tierra y a la devastación de los recursos naturales, propiciada por la inconsciencia y la explotación, la investigadora Chantal Maillard decidió reunir una serie de ensayos, con el fin de proponer una nueva actitud frente a los problemas ecológicos, y, sobre todo, buscar una integración con la naturaleza que tenga como base el conocimiento del otro -del entorno natural- a partir de la contemplación, ya que "quien contempla está vacío de sí mismo y ese vacío lleno de posibilidades en el suelo común, propiamente común de lo humano”. La contemplación, entonces, no debe ser entendida como un hecho esotérico, sino más bien como una apertura, una empatía con el resto de los seres vivos; como una actitud ecosófica. ¿Ecosófica o ecológica? Si partimos de la idea de que la ecología parte del logos, del conocimiento científico que exige objetividad y por lo tanto distancia, comprenderemos el sentido real de la ecosofía, término acuñado por uno de los colaboradores de El árbol de la vida: Raimon Panikkar, quien afirma que "Conocer los lirios es más que situarlos en el espacio, o en el tiempo, o analizar sus funciones y sus partes. Conocer es más que clasificar y que ser capaces de predecir comportamientos.” El conocimiento implica más que la razón, la verdadera sabiduría que es incluyente y sensible. No resulta vano que el origen de todos los conceptos surja de la experiencia, de lo percibido y retenido por la memoria en forma de imágenes recreadas. La palabra es el origen del pensamiento, Vac-como se dice en el Rig Veda- es ese ente que le da nombre a las cosas y, de este modo, se adueña 'de todas las existencias'. Esto nos sugiere que el lenguaje, el concepto, contiene en sí la esencia del Ser tangible o inconmensurable como lo es el amor o el mismo Brahman (lo Absoluto) del hinduismo.

La filosofía, la religión y el arte se hallan muy cercanas entre sí, debido a que poseen elementos y conceptos en común, pertenecientes a una forma de 


\section{RESEÑAS}

enfrentar el mundo. En este sentido, es preciso recordar la importancia de la dialéctica y la reflexión del Anekantavada o teoría de la relatividad conceptual, proveniente de los jainas de la India, grupo que defiende la vida de todos los seres vivos y la coexistencia de diversas interpretaciones del mundo, aunque éstas sean opuestas o contradictorias. Al respecto, resulta muy ilustrativo el ensayo del Dr. Juan Miguel de Mora, titulado "Ecología jaina y Anekantavada”. La postura ecológica de los jainas penetró en el hinduismo y se asimiló a la mitología y a las filosofías hindúes, incluyendo el lokayata o materialismo ateo, donde no se pierde de vista la integración del hombre en la naturaleza y no la de la naturaleza en el hombre, tal como lo ha querido el sistema del mercado occidental.

Ahora bien, ¿¿cómo negar el contexto de nuestro presente y asumir una concepción hoy tan ajena y distante como la que nos muestra el arte y las tradiciones de la India? Justamente, el propósito del libro editado por Maillard es acercamos a esta visión ecléctica y sincrética de la antigua India, mediante la sensibilización léxica, producida por una serie de ensayos que no sólo hablan de la realidad de la antigua India o de sus manifestaciones culturales en el arte y la filosofía, sino también de nuestra cotidianidad como seres humanos, como habitantes de un planeta semidestruido por razones de toda índole: económicas, políticas, sociales y religiosas. Se trata, pues, de partir de una tradición, en la actualidad elitista, para comprender las causas por las que la naturaleza y el arte o la energía creadora se reúnen en el lugar más sublime del hombre, en dónde se origina, a partir de la contemplación, la verdadera sabiduría: la mente con ayuda de sus sentidos internos y externos. Con este propósito, Maillard dividió los textos en dos partes: la primera se titula "Naturaleza y tradición”; la segunda, "Naturaleza y arte”. En la primera parte leemos los textos de Raimon Panikkar, Óscar Pujol, Juan Miguel de Mora, Rada Ivekovic, Kapila Vatsyayan y María Ludwika Jarocka, en los cuales se retoman algunas particularidades de ciertos mitos, textos sagrados y tradiciones antiguas vinculadas al cuidado de los recursos naturales. Tal vez, el único artículo que rompe con la especificidad y el carácter informativo, que predomina en el resto, es el de Panikkar, quien de manera concisa, clara y coherente plantea de modo general el problema y la ineficacia de la ecología para postular su 'ecosofía', propuesta original y nada descabellada. Maillard tuvo el acierto de colocar dicho artículo al principio, pues reitera los motivos por los que se hacía necesaria la edición de un libro como El árbol de la vida. 
RESEÑAS

En la segunda parte se introduce un elemento que ya se iba vislumbrando desde el inicio: el arte. Autores como Bettina Bäumer, K. D. Trpathi, Rosa Fernández Gómez, Carmen García-Ormaechea y Eva Fernández del Campo Barbadillo nos hablan de la estética hindú y de los simbolismos que encarnan las figuras del fuego, el agua, la tierra y el aire. Asimismo, se incluye aquí un texto de Ananda Coomaraswamy, considerado uno de los más importantes orientalistas. De hecho, el título del libro que nos ocupa se debe al ensayo de Coomaraswamy, "El árbol de la vida, el loto de la tierra y la rueda de la palabra." Su autor -ya difunto- desea recalcar los simbolismos que encarnan las figuras del árbol y el loto, como bases mitológicas de la India y su importancia en la conformación de discursos e iconografías de índole artística, sin dejar de ser -por ello- significativas y sensibles a una multitud de interpretaciones. No es extraño que si el árbol es símbolo de la vida, de lo femenino, de la fertilidad y de las fuerzas creadora y conservadora, el loto haya encontrado un lugar en el pensamiento hinduista, budista y jainista como la conexión perfecta entre el agua, la tierra y el aire, elementos primordiales de la vida y, por lo tanto, de la mitología hindú. El mito es indispensable para la creación artística en las culturas antiguas; sin éste y sin lo que lo motiva, es decir, el entorno que todo lo devora y lo contiene, no tendrían razón de ser ni la creación humana ni el pensamiento mismo. De ahí la urgencia de rescatar todo aquello que motiva la vida, pero que también fomenta la existencia del arte, de la liberación espiritual del hombre. En realidad, la naturaleza, al ser madre de lo que existe materialmente sobre la Tierra, funge como progenitora de los sentidos y sensaciones conceptualizadas por la razón humana, que ella misma engendró. La conciencia que debemos tomar tiene que trascender toda hipótesis para ser sentida y asumida. No se trata de que la India moderna y hasta cierto punto occidentalizada vuelva al pasado tal y como fue, ya que resultaría absurdo e imposible; tampoco se pretende que Occidente adopte la idiosincrasia de un pueblo con realidades y percepciones casi radicalmente opuestas a las suyas, sino más bien de buscar una revalorización de lo que el hombre pensó en algún momento y lugar determinados. Ese pasado no volverá, pero ¿por qué no tomar ciertos aspectos de ese tiempo perdido para construir uno, sino semejante, por lo menos atractivo en su naturalidad?

\author{
MARCELA SOLÍS-QUIROGA \\ Facultad de Filosofía y Letras, UNAM
}

